\title{
Legume Friend Rizobium and Booster Sulphur
}

\author{
Sonali Srivastava $^{1 *}$, S.P. Tiwari ${ }^{2}$ and Vatsal Srivastav ${ }^{3}$ \\ ${ }^{1}$ Department of Microbiology, V.B.S.P.U Jaunpur, India \\ ${ }^{2}$ Department of Microbiology, Faculty of applied Science, V.B.S. Purvanchal University \\ Jaunpur, India \\ ${ }^{3}$ Vatsal Srivastav Teacher CARS Narayanpur, India \\ *Corresponding author
}

\begin{tabular}{|l|}
\hline Ke y w or d s \\
Rhizobium, \\
Sulphur, Noduls \\
\hline Article Info \\
\hline $\begin{array}{l}\text { Accepted: } \\
10 \text { March } 2019 \\
\text { Available Online: } \\
10 \text { April } 2019\end{array}$ \\
\hline
\end{tabular}

\section{A B S T R A C T}

An experiment was designed to assess the response of Sulphur to different Chickpea cultivars at Agriculture farm of Mahatma Gandhi Chitrakoot Gramodaya Vishwavidyalaya, Chitrakoot, Satna (M.P.). Three varieties (DCP 92-03, JG-16, JG-11) Seed Treatment in Chickpea with Rhizobium and three Sulphur levels (10, 20, 30 and 40 $\mathrm{kg} \mathrm{S} \mathrm{/ha)} \mathrm{along} \mathrm{with} \mathrm{all} \mathrm{possible} \mathrm{interactions} \mathrm{were} \mathrm{used.} \mathrm{Experimental} \mathrm{design} \mathrm{fallowing}$ split plot design in three replications was employed data was collected on yield parameters. Rhizobium species form an endosymbiotic nitrogen-fixing association with roots of legumes and Parasponia. The bacteria colonize plant cells within root nodules, where they convert atmospheric nitrogen into ammonia using the enzyme nitrogenase and then provide organic nitrogenous compounds such as glutamine or ureides to the plant. Sulfur is an essential nutrient for plants because it is a constituent of the amino acids cysteine (Cys) and methionine (Met), metal cofactors, coenzymes, and secondary metabolites. The application of $40 \mathrm{~kg} \mathrm{~S} / \mathrm{ha}-1$ enhanced the plant height, number of branches, No. of nodule, nodule dry weight, no. of pods / plant, no. of seeds / plant, seed weight / plant, 100 seed weight (g) / plot, significantly over S1, S2, S3. This reflects the fact that sulphur only up to $30 \mathrm{~kg} / \mathrm{ha}-1$ ( $40 \mathrm{Kg} \mathrm{S} / \mathrm{ha}-1)$ was sufficient to meet the requirement of the actively growing plants under the existing sulphur status of the soil.

\section{Introduction}

This Project work is about the bacterial genus and sulphur element. For the generic term that includes species in other genera, see Rhizobia. Rhizobium is a genus of Gram negative soil bacteria that fix nitrogen. Sulfur is an essential nutrient for plants because it is a constituent of the amino acids cysteine (Cys) and methionine (Met), metal cofactors, coenzymes, and secondary metabolites (reviewed by Davidian and Kopriva, 2010). As occurs in other plants, sulfur deficiency in legumes decreases plant growth, photosynthesis, and yield. However, nodulated legumes have a high demand for sulfur and SNF is more sensitive to sulfur deficiency than is nitrate uptake (Zhao et al., 1999; Varin et al., 2010). 
The plant, in turn, provides the bacteria with organic compounds made by photosynthesis. This mutually beneficial relationship is true of all of the rhizobia, of which the genus Rhizobium is a typical example. Martinus Beijerinck was the first to isolate and cultivate a microorganism from the nodules of legumes in 1888. He named it Bacillus radicicola, which is now placed in Bergey's Manual of Determinative Bacteriology under the genus Rhizobium. Rhizobium forms a symbiotic relationship with certain plants such as legumes, fixing nitrogen from the air into ammonia, which acts as a natural fertilizer for the plants.

\section{Experimental site and Location}

The experiment was conducted, during the Ravi season of 2015 - 16 at the Agriculture Farm of Mahatma Gandhi Chitrakoot, Gramodaya Vishwavidyalaya, Chitrakoot Satna (Madhya Pradesh) located from 2431' $\mathrm{N}$ latitude and $81^{\circ} 15^{\prime} \mathrm{E}$ latitude. The experimental field is situated in the North Eastern part of Madhya Pradesh. All the facilities necessary for conducting the experiment, including labour and resources, which were necessary for normal cultivation were readily available in the department.

\section{Experimental design and layout details}

To achieve the objectives the field experiment was conducted in split plot design with three replications having 12 treatments combination. The details of are given in Table 1 .

\section{Details of treatments}

\section{Main-plot treatment: Varieties-3}

1- DCP 92-03 $\left(\mathrm{V}_{1}\right)$ 2- JG-16 $\left(\mathrm{V}_{2}\right)$ 3- JG-11 $\left(\mathrm{V}_{3}\right)$
Varietty - DCP 92-03, Source - IIPR, Year of Release/Notification - 1997, Area of adoption zone/ state - North West plane zone (Punjab, Haryana, Delhi, North Rajasthan, west U.P), Area yield (Q/ha)- 19-20, Days to Maturity 145-150, Remarks - Lodging and wilt resistant yellowish Brown and excessive moisture conditions.

Variety - JG-16, Source - JNKV, Year of Release/Notification - 2001, Area of adoption zone/ state - M.P, Maharashtra, Gujarat, Area yield (Q/ha) - 18-20, Days to Maturity- 120125, Remarks - JG 16: Maturity: 110-115 days, Seed size: 22-25 g, Seed yield: 18-20 q/ha, Semi spreading, profuse branching, dark green foliage, light brown, medium bold, attractive seed, rainfed.

Variety - JG-11, Source - JNKV, Year of Release/Notification -1997, Area of adoption zone/, state - M.P, Area yield (Q/ha) -13-15 Days to Maturity -120-125, Remarks- Seed pinkish, JG 11 (ICCV 93954) is a desi chickpea varieties developed through collaborative breeding efforts of ICRISAT with Jawaharlal Nehru Krishi Vishwa Vidyalaya (JNKVV), Jabalpur, Madhya Pradesh, India, and released in 1999.

This is the most preferred variety by farmers in India because of its early maturity (95-100 d) and higher yield (up to $2.5 \mathrm{t} \mathrm{ha}^{-1}$ in rain-fed and up to $3.5 \mathrm{t} / \mathrm{ha}^{-1}$ under irrigated conditions) than the other varieties with an attractive large seed (22 g per 100 seed).JG 11 brought the chickpea revolution in Andhra Pradesh by covering $70 \%$ area with potential yield of $36.0 \mathrm{q} / \mathrm{ha}$ by replacing age old wide adopted variety Annagiri (Table 2).

\section{Sub-plot treatment: Sulphur levels -4}
$1.10 \mathrm{~kg} \mathrm{~S} / \mathrm{ha}\left(\mathrm{S}_{1}\right)$.
2. $20 \mathrm{~kg} \mathrm{~S} / \mathrm{ha}\left(\mathrm{S}_{2}\right)$.
3. 30kg S/ha $\left(\mathrm{S}_{3}\right)$.
4. $40 \mathrm{~kg} \mathrm{~S} / \mathrm{ha}\left(\mathrm{S}_{4}\right)$. 


\section{Treatment combination}

\section{Nodulation}

Three plants at random were uprooted from each pot causing minimum damage to the roots at 75 DAS of the crop. The roots were thoroughly washed with a jet of water, and then nodules were removed from roots with the help of forceps. The effective nodules were counted and data recorded for three plants uprooted from each plot. These nodules were dried at $70 \pm 1^{\circ} \mathrm{C}$ for $2-3$ days. Then oven dry weight of nodules was recorded.

\section{Results and Discussion}

\section{Nodulation observation}

Observations on nodulation were taken on 75 DAS stage and results of these parameters are presented in Table 4.

\section{Nodules number}

The data presented in table 4 indicated that the different chickpea cultivars and sulphur levels increased the nodule number and their dry weight/plant significantly at 75 DAS stage

\section{Effect of varieties}

The nodule number noted in the range of 6.01 -11.16. par plant under different varieties of chickpea. Whereas, variety DCP 92-03 $\left(\mathrm{V}_{1}\right)$ also recorded significantly higher (11.16 / Plant) nodule number over JG-16 $\left(\mathrm{V}_{2}\right)$ and JG-11 $\left(\mathrm{V}_{3}\right)$.

\section{Effect of sulphur levels}

It is seen from the data in Table 4, that the increasing level of sulphur increased the nodule number per plant significantly. Maximum nodule number (08.39 / plant) was observed in $40 \mathrm{~kg} \mathrm{~S} / \mathrm{ha}\left(\mathrm{S}_{4}\right)$ levels which was significantly superior over $10 \mathrm{~kg} \mathrm{~S} /$ ha $\left(\mathrm{S}_{1}\right)$ and $20 \mathrm{~kg} \mathrm{~S} / \mathrm{ha}\left(\mathrm{S}_{2}\right)$ levels but statistically at par with $30 \mathrm{~kg} \mathrm{~S} / \mathrm{ha}\left(\mathrm{S}_{3}\right)$ level.

\section{Interaction effects}

The interaction effect due to varieties and sulphur levels on nodule number plant was found to the non -significant at 75 DAS stages of growth.

\section{Nodule dry wright}

Data on nodule dry weight have been set out in Table 4.

\section{Effect of varieties}

The nodule dry weight observed in the range of $6.8 \mathrm{mg}-13.8 \mathrm{mg}$ per plant under different varieties of chickpea. Variety DCP 92-03 $\left(\mathrm{V}_{1}\right)$ recorded maximum nodule dry weight (13.8 mg / plant) which was significantly superior over remaining two varieties under tested. Whereas, JG-16 $\left(\mathrm{V}_{2}\right)$ also recorded higher nodule dry wright over JG-11 $\left(\mathrm{V}_{3}\right)$ of significance.

\section{Effect of sulphur levels}

It is seen from the data (Table 4) that the increasing level of sulphur increased the nodule dry weight per plant significantly. Maximum nodule dry weight (9.96 g /plant) was noted with $40 \mathrm{~kg} \mathrm{~S} / \mathrm{ha}\left(\mathrm{S}_{4}\right)$ level which was significantly superior over $10 \mathrm{~kg} \mathrm{~S} /$ ha $\left(\mathrm{S}_{1}\right)$ and $20 \mathrm{~kg} \mathrm{~S} / \mathrm{ha}\left(\mathrm{S}_{2}\right)$ but statistically at par with $30 \mathrm{~kg} \mathrm{~S} / \mathrm{ha}\left(\mathrm{S}_{3}\right)$ level.

\section{Interaction effects}

The interaction effect due to varieties and sulphur levels on nodule dry weight / plant was found to the non-significant at 75 DAS stages of growth. 


\section{Economics}

Recommendation and adoption of any practices by cultivators depends upon its economics. Therefore, it becomes essential to work out economics of the treatments tested for judging the best treatments under study, for getting higher net profit per hectare.

\section{Effect of sulphur levels}

Under different levels of sulphur $40 \mathrm{~kg} \mathrm{~S} / \mathrm{ha}^{-1}$ $\left(\mathrm{S}_{4}\right)$ gave highest gross and net income of Rs.83289 / ha ${ }^{-1}$ and Rs. $57574 /$ ha $^{-1}$ which is followed by $30 \mathrm{~kg} \mathrm{~S} / \mathrm{ha}^{-1}\left(\mathrm{~S}_{3}\right)$ with Gross returns (Rs.66416/ha ${ }^{-1}$ and Net returns Rs.41401) and minimum (Gross returns Rs.47871 and Net returns Rs.24255/ha ${ }^{-1}$ ) under $10 \mathrm{~kg} \mathrm{~S} / \mathrm{ha}^{-1}\left(\mathrm{~S}_{1}\right)$.
Highest net income of Rs.57574 / ha $\mathrm{h}^{-1}$ and B:C ratio (3.14) were recorded with $40 \mathrm{~kg} \mathrm{~S} \mathrm{/}$ $\mathrm{ha}^{-1}\left(\mathrm{~S}_{4}\right)$ respectively (Table 5).

\section{Effect of sulphur}

It is evident from the results reported in foregoing pages, that the application of $40 \mathrm{~kg}$ $\mathrm{S} / \mathrm{ha}^{-1}$ enhanced the plant height, number of branches, No. of nodule, nodule dry weight, no. of pods/plant, no. of seeds/plant, seed weight/plant, 100 seed weight (g)/plot, significantly over $S_{1}, S_{2}, S_{3}$. This reflects the fact that sulphur only up to $30 \mathrm{~kg} / \mathrm{ha}^{-1}(40 \mathrm{Kg}$ $\mathrm{S} / \mathrm{ha}^{-1}$ ) was sufficient to meet the requirement of the actively growing plants under the existing sulphur status of the soil.

Table.1 Experimental design and layout details

\begin{tabular}{|l|l|l|}
\hline $\mathbf{1}$ & Design & Split plot \\
\hline $\mathbf{2}$ & Treatments & $12(3$ varieties and 4 Sulphur level) \\
\hline $\mathbf{3}$ & Replications & 03 \\
\hline $\mathbf{4}$ & Number of plots & 36 \\
\hline $\mathbf{5}$ & Gross plot size & $5.0 \mathrm{~m} \times 3.0 \mathrm{~m}$ \\
\hline $\mathbf{6}$ & Net plot size & $4.0 \mathrm{~m} \times 2.10 \mathrm{~m}$ \\
\hline $\mathbf{7}$ & Replication border & $1.0 \mathrm{~m}$ \\
\hline $\mathbf{8}$ & Distance between plots & $0.5 \mathrm{~m}$ \\
\hline $\mathbf{9}$ & Distance between plots & $30 \mathrm{~cm}$ \\
\hline $\mathbf{1 0}$ & $100 \%$ RDF & $20 \mathrm{~kg} \mathrm{~N}+40 \mathrm{~kg} \mathrm{P}_{2} \mathrm{O}_{5}+20 \mathrm{~kg} \mathrm{~K}_{2} \mathrm{O} / \mathrm{ha}$ \\
\hline $\mathbf{1 1}$ & Seed rate & $80 \mathrm{~kg} / \mathrm{ha}$ \\
\hline
\end{tabular}

Table.2 Treatment combinations and symbols used

\begin{tabular}{|l|l|l|l|l|l|}
\hline S. No. & \multicolumn{4}{|l|}{ Treatments } \\
\hline $\mathbf{1}$ & $\mathbf{T}_{\mathbf{1}}$ & $\mathrm{S}_{1} \mathrm{~V}_{1}$ & 7 & $\mathbf{T}_{\mathbf{7}}$ & $\mathrm{S}_{3} \mathrm{~V}_{1}$ \\
\hline $\mathbf{2}$ & $\mathbf{T}_{\mathbf{2}}$ & $\mathrm{S}_{2} \mathrm{~V}_{2}$ & 8 & $\mathbf{T}_{\mathbf{8}}$ & $\mathrm{S}_{4} \mathrm{~V}_{2}$ \\
\hline $\mathbf{3}$ & $\mathbf{T}_{\mathbf{3}}$ & $\mathrm{S}_{3} \mathrm{~V}_{3}$ & 9 & $\mathbf{T}_{\mathbf{9}}$ & $\mathrm{S}_{1} \mathrm{~V}_{3}$ \\
\hline $\mathbf{4}$ & $\mathbf{T}_{\mathbf{4}}$ & $\mathrm{S}_{4} \mathrm{~V}_{1}$ & 10 & $\mathbf{T}_{\mathbf{1 0}}$ & $\mathrm{S}_{2} \mathrm{~V}_{1}$ \\
\hline $\mathbf{5}$ & $\mathbf{T}_{\mathbf{5}}$ & $\mathrm{S}_{1} \mathrm{~V}_{2}$ & 11 & $\mathbf{T}_{\mathbf{1 1}}$ & $\mathrm{S}_{3} \mathrm{~V}_{2}$ \\
\hline $\mathbf{6}$ & $\mathbf{T}_{\mathbf{6}}$ & $\mathrm{S}_{2} \mathrm{~V}_{2}$ & 12 & $\mathbf{T}_{\mathbf{1 2}}$ & $\mathrm{S}_{4} \mathrm{~V}_{3}$ \\
\hline
\end{tabular}


Table.3 Details of pre and post sowing operations

\begin{tabular}{|l|l|l|}
\hline S. No & Operation & Dates \\
\hline $\mathbf{1}$ & Harrowing\& Ploughing & $30 / 10 / 2015$ \\
\hline $\mathbf{2}$ & Ploughing -II \& Leveling (Planking) & $06 / 11 / 2015$ \\
\hline $\mathbf{3}$ & Layout formation and soil sample & $06 / 11 / 2015$ \\
\hline $\mathbf{4}$ & Fertilizer application (basal) and Sowing & $07 / 11 / 2015$ \\
\hline $\mathbf{5}$ & Date of irrigation & $17 / 11 / 2015$ \\
\hline $\mathbf{6}$ & Resowing & $21 / 11 / 2015$ \\
\hline $\mathbf{7}$ & Thinning & $05 / 12 / 2015$ \\
\hline $\mathbf{8}$ & First hand weeding & $08 / 12 / 2015$ \\
\hline $\mathbf{9}$ & Date of Second irrigation & $19 / 12 / 2015$ \\
\hline $\mathbf{1 0}$ & First observed taken & $21 / 12 / 2015$ \\
\hline $\mathbf{1 1}$ & Second observed taken & $06 / 01 / 2016$ \\
\hline $\mathbf{1 2}$ & Third observation taken & $22 / 01 / 2016$ \\
\hline $\mathbf{1 3}$ & Nodulation study & $05 / 02 / 2016$ \\
\hline $\mathbf{1 4}$ & Date of Third irrigation & $10 / 02 / 2016$ \\
\hline $\mathbf{1 5}$ & Second hand weeding & $20 / 02 / 2016$ \\
\hline $\mathbf{1 6}$ & Harvesting & $20 / 03 / 2016$ \\
\hline & & \\
\hline
\end{tabular}

Table.4 Effect of varieties and sulphur levels on nodulations of chickpea. (75 DAS)

\begin{tabular}{|c|c|c|}
\hline \multirow{2}{*}{$\begin{array}{l}\text { Treatment } \\
\text { (A) Cultivars }\end{array}$} & \multicolumn{2}{|c|}{ Number of nodulation at 75 DAS } \\
\hline & Nodule number & Nodule dry weight $(\mathrm{mg})$ \\
\hline$V_{1}:$ DCP 92-03 & 11.16 & 13.8 \\
\hline$V_{2}:$ JG-16 & 6.37 & 7.0 \\
\hline$V_{3}:$ JG-11 & 6.01 & 6.8 \\
\hline S.E $\mathbf{m} . \pm$ & 0.3438 & .2163 \\
\hline C.D. $(P=0.05)$ & 1.0216 & .6426 \\
\hline \multicolumn{3}{|c|}{ (B) Sulphur levels (kg S/ha $\left.{ }^{-1}\right)$} \\
\hline$S_{1}: 10$ & 6.58 & 8.38 \\
\hline$S_{2}: 20$ & 7.66 & 8.95 \\
\hline $\mathrm{S}_{3}: \mathbf{3 0}$ & 8.21 & 9.65 \\
\hline$S_{4}: 40$ & 8.93 & 9.96 \\
\hline S.E. m. \pm & 0.22 & 0.21 \\
\hline C.D. $(P=0.05)$ & 0.68 & 0.61 \\
\hline Interaction & (N.S) & (N.S) \\
\hline
\end{tabular}


Table.5 Economics

\begin{tabular}{|c|c|c|c|c|}
\hline Treatment & $\begin{array}{l}\text { Cost } \\
\text { Cultivation } \\
\left(\text { Rs./ha }^{-1}\right)\end{array}$ & $\begin{array}{l}\text { Gross returns } \\
(\text { Rs./ha-1 })\end{array}$ & $\begin{array}{l}\text { Net } \\
\text { returns } \\
\left(\text { Rs./ha }^{-1}\right)\end{array}$ & B:C Ratio \\
\hline$V_{1}$ DCP 92-03 & 27465 & 104989 & 77524 & 3.805 \\
\hline$V_{2} J G-16$ & 23265 & 42247 & 18982 & 1.8025 \\
\hline$V_{3}$ JG- 11 & 23265 & 46147 & 22882 & 1.98 \\
\hline$S_{1} 10 \mathrm{~kg} \mathrm{~S} / \mathrm{ha}^{-1}$ & 23616 & 47871 & 24255 & 1.97 \\
\hline$S_{2} 20 \mathrm{~kg} \mathrm{~S} / \mathrm{ha}^{-1}$ & 24315 & 60268 & 35953 & 2.41 \\
\hline$S_{3} 30 \mathrm{~kg} \mathrm{~S} / \mathrm{ha}^{-1}$ & 25015 & 66416 & 41401 & 2.8 \\
\hline$S_{4} 40 \mathrm{~kg} \mathrm{~S} / \mathrm{ha}^{-1}$ & 25715 & 83289 & 57574 & 3.14 \\
\hline $\mathbf{V}_{1} \mathbf{S}_{1}$ & 26416 & 75464 & 49048 & 2.86 \\
\hline $\mathbf{V}_{1} \mathbf{S}_{2}$ & 27115 & 98306 & 71191 & 3.63 \\
\hline $\mathbf{V}_{1} \mathbf{S}_{3}$ & 27815 & 106711 & 78896 & 3.84 \\
\hline $\mathbf{V}_{1} \mathbf{S}_{4}$ & 28515 & 139474 & 110959 & 4.89 \\
\hline $\mathbf{V}_{2} \mathbf{S}_{1}$ & 22216 & 29940 & 7724 & 1.35 \\
\hline $\mathbf{V}_{2} \mathbf{S}_{2}$ & 22915 & 38498 & 15583 & 1.68 \\
\hline $\mathbf{V}_{2} \mathbf{S}_{3}$ & 23615 & 41375 & 17760 & 1.75 \\
\hline $\mathbf{V}_{2} \mathbf{S}_{4}$ & 24315 & 59176 & 34861 & 2.43 \\
\hline $\mathbf{V}_{3} \mathbf{S}_{1}$ & 22216 & 38208 & 15992 & 1.72 \\
\hline $\mathbf{V}_{3} \mathbf{S}_{2}$ & 22915 & 44001 & 21086 & 1.92 \\
\hline $\mathbf{V}_{3} \mathbf{S}_{3}$ & 23615 & 51163 & 27548 & 2.17 \\
\hline $\mathbf{V}_{3} \mathbf{S}_{4}$ & 24315 & 51218 & 26903 & 2.11 \\
\hline
\end{tabular}

Fig.1 Nodules number

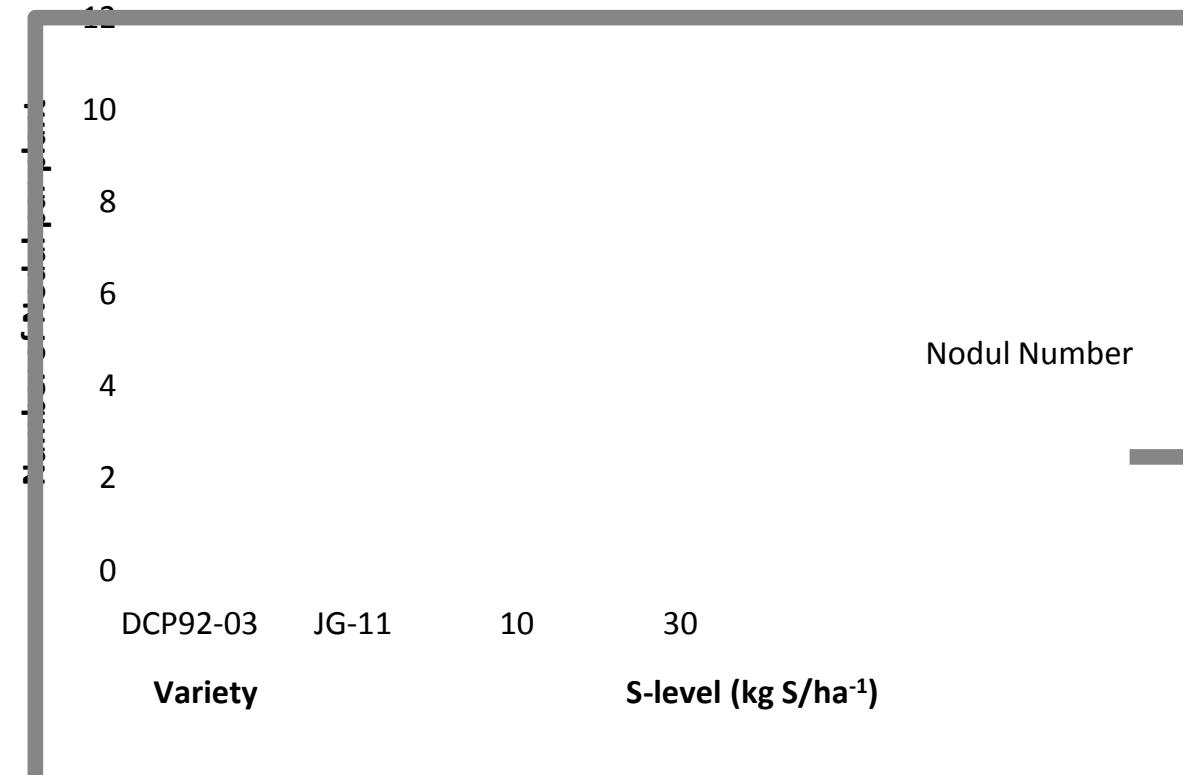


Fig.2 Nodule dry weight (g)

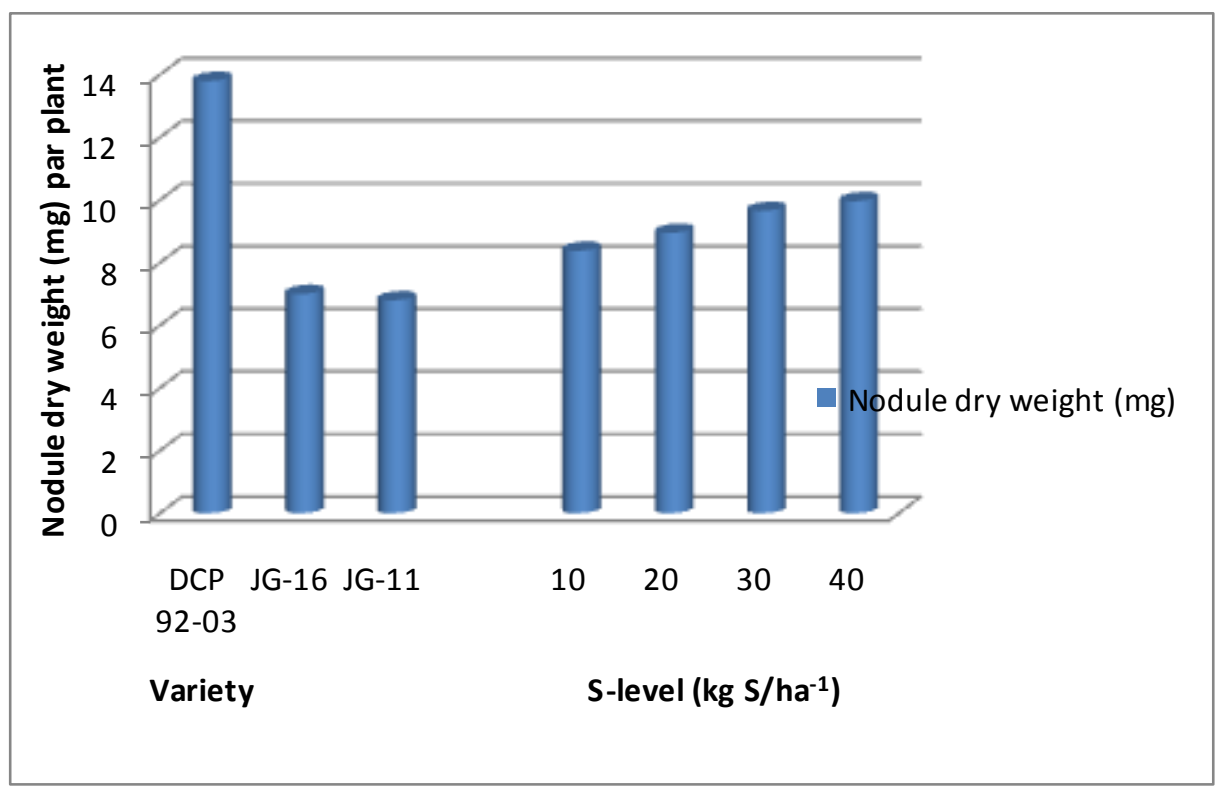

An improvement in plant growth parameters by increasing doses of sulphur might be because of its role in the formation of amino acids viz, cysteine, methionine and synthesis of protein, vitamin and chlorophyll. The findings corroborates with the findings of Shri Krishna et al., (2004), Muhammad Islam et al., (2013), Togay et al., (2008), Sher Singh (2004), Shivakumar (2001), Dwivedi et al., (1982), Chaudhary and Goswami (2005) and Sharma and Kushwah (2011) in chickpea crop in different parts of India.

Maximum nodule number (08.39 / plant) was observed in $40 \mathrm{~kg} \mathrm{~S} / \mathrm{ha}\left(\mathrm{S}_{4}\right)$ levels which was significantly superior over $10 \mathrm{~kg} \mathrm{~S} / \mathrm{ha}^{-1}\left(\mathrm{~S}_{1}\right)$ and $20 \mathrm{~kg} \mathrm{~S} / \mathrm{ha}^{-1}\left(\mathrm{~S}_{2}\right)$ levels but statistically at par with $30 \mathrm{~kg} \mathrm{~S} / \mathrm{ha}^{-1}\left(\mathrm{~S}_{3}\right)$ level.

Maximum nodule dry weight $(9.66 \mathrm{mg} / \mathrm{plant})$ was noted with $40 \mathrm{~kg} \mathrm{~S} / \mathrm{ha}\left(\mathrm{S}_{4}\right)$ level which was significantly superior over $10 \mathrm{~kg} \mathrm{~S} / \mathrm{ha}^{-1}$ $\left(\mathrm{S}_{1}\right)$ and $20 \mathrm{~kg} \mathrm{~S} / \mathrm{ha}^{-1}\left(\mathrm{~S}_{2}\right)$ but statistically at par with $30 \mathrm{~kg} \mathrm{~S} / \mathrm{ha}^{-1}\left(\mathrm{~S}_{3}\right)$ level.

The improvement in nodules per plant and consequently their dry weight might be due to adequate supply of sulphur to plants which helps in stimulation the Rhizobium bacteria for nodule formation. These results confirmed the findings of Kasturikrishna and Sher singh (2004), Shivkumar (2001), Muhammad Islam (2013), Togay (2008). Deo and Khaldelwal (2009) and Sharma and Kushwah (2011) The probable reason may be due to adequate supply of sulphur might have played an important physiological role by enhancing cell multiplication, elongation, expansion and chlorophyll biosynthesis, which is turn increased the assimilate production to be used for root development also.

These results confirmed the findings of Kasturkrishna and Ahlawat (2000), and Sharma and Kushwah (2011) it is revealed from the results reported in foregoing pages that the sulphur addition $40 \mathrm{~kg} / \mathrm{ha}^{-1}$ significantly increased seed yield of chickpea. This increase in seed yield might have resulted from the efficient and greater partitioning of metabolites and adequate translocation of photosynthesis towards the developing reproductive structure (Fig. 1 and 2). 
Although increase the straw yield significantly but the difference between straw yields under various sulphur levels was statistically at par. the straw yield might because of higher growth parameters as well as greater nodulation and root development. The probable reason may be due to adequate supply of all the nutrients, which resulted in greater accumulation of carbohydrates, amino acids and their translocation to the productive organs, which, in turn improved all the growth and yield attributing characters. The findings corroborates with the findings of Mondal et al., (2005), Chaudhary and Goswami (2005), Kumar et al., (2009). Tripathi et al., (2011) and Sharma and Kushwaha (2011).

\section{References}

Anderson, A. J., and Spencer, D. (1950). Sulphur in nitrogen metabolism of legumes and non-legumes. Aust. J. Sci. Res. 3, 414-430

Chaudhary, V. K and Goswami, V. K (2005)Effect of phosphorus and sulphur fertilization on chickpea (Cicer arietinum L.) cultivar. Annals of Agricultural Research.26 (2) 322-323.

Davidian, J. C., and Kopriva, S. (2010). Regulation of sulfate uptake and assimilation -the same or not the same? Mol. Plant. 3, 314-325. doi: $10.1093 / \mathrm{mp} / \mathrm{ssq} 001$

Deo, Chandra and Khaldehwal, R. B.(2009)Effect of $\mathrm{P}$ and $\mathrm{s}$ nutrition on yield of chickpea. Journal of Science, 57(3): 352-356.

Dwivedi, G. K. and Singh, V. P (1982) Indian Journal of Agronomy, 1982, 27, 1, 712,9

Kasturikrishna, S. and Ahlawat, 1. P. S. (2000) Effect of moisture stress and phosphorus, sulphur and zinc fertilizers on growth and development of pea (Pisum sativum), Indian Journal of Agronomy, 45(3): 353. 356

Kumar Dushyant, Verma, R. N. and Tripathi, H. N (2009) Productivity and economics of breeder seed of chickpea (Cicer arietinum L.) as affected by sowing methods, seed rates and sulphur levels Research on Crops, 1001) 42-47.

Mondal, S. S. Manual, P. Saha, M. Bag, A Nayak, S. Sounda, G. (2005) Effect of potassium and sulphur on the productivity, nutrient uptake and quality improvement of chickpea. Journal of Crop and Weed 1(2):84-86.

Muhammad Islam, Muhammad Akmal; Khan, M.A (2013). National Agricultural Research and Development Institute, Fundulea, Romania, Romanian Agricultural Research, 2013, 30, 223232, 34

Shivakumar, B. G (2001) Indian Society of Agronomy, New Delhi, India, Indian Journal of Agronomy, 2001 Performance of chickpea (Cicer arietinum) varieties as influenced by sulphur with and without phosphorus

Scherer, H. W. (2008). "Impact of sulfur on $\mathrm{N}_{2}$ fixation of legumes," in Sulfur Assimilation and Abiotic Stress in Plants, eds N. A. Khan, S. Singh, and S. Umar (Berlin: Springer-Verlag), 43-54. doi: 10.1007/978-3-54076326-0_3

Sharma, Vaishali and Kushwaha, H. S.(2011)Productivity and profitability of chickpea as influenced by FYM, Sulphur and zinc under rainfed condition of central India. Ann. Pl. Soil Res., 13(2): 112-115.

Singh, R. V. Sharma, A. K. Tomar, R. K. S. (2003). Response of chickpea to sources and levels of sulfur. International Chickpea and Pigeon pea Newsletter; (10): 20-21.

Shri Krishna Sharma, A. P. Chandra Bhushan 
(2004) Nitrogen and sulphur nutrition of chickpea (Cicer arietinum L.) grown under semiarid conditions of Central Uttar Pradesh. Legume Research 27(2):146- 148

Togay, N.Togay, Y. Cimrin, K. M. Turan (2008) Academic Journals, Nairobi, Kenya, African Journal of Biotechnology, 2008, 7, 6, 776-782, 25 ref

Tripathi. H. C. Pathak, R. K., Kumar Anil and Dimree, S. (2011) Effect of Sulphur and Zinc on yield attributes, yield and nutrient uptake in chickpea. Ann. Pi
Soil Res, 13(2): 134-136.

Varin, S., Cliquet, J.-B., Personeni, E., Avice, J.-C., and Lemauviel-Lavenant, S. (2010). How does sulphur availability modify $\mathrm{N}$ acquisition of white clover (Trifolium repens L.)? J. Exp. Bot. 61, 225-234. doi: 10.1093/jxb/erp303.

Zhao, F. J., Wood, A. P., and McGrath, S. P. (1999). Effects of sulphur nutritionon growth and nitrogen fixation of pea (Pisum sativum L.). Plant Soil 212, 207-217. doi: 10.1023/A:100461 8303445

\section{How to cite this article:}

Sonali Srivastava, S.P. Tiwari and Vatsal Srivastav. 2019. Legume Friend Rizobium and Booster Sulphur. Int.J.Curr.Microbiol.App.Sci. 8(04): 1033-1041. doi: https://doi.org/10.20546/ijcmas.2019.804.120 